\section{Are plutons assembled over millions of years by amalgamation from small magma chambers?}

\author{
Allen F. Glazner, Department of Geological Sciences, \\ CB\#3315, University of North Carolina, Chapel Hill, North \\ Carolina 27599, USA, afg@unc.edu
}

John M. Bartley, Department of Geology and Geophysics, University of Utah, Salt Lake City, Utah 84112, USA

Drew S. Coleman, Walt Gray*, and Ryan Z. Taylor*, Department of Geological Sciences, CB\#3315, University of North Carolina, Chapel Hill, North Carolina 27599, USA

\begin{abstract}
Field and geochronologic evidence indicate that large and broadly homogeneous plutons can accumulate incrementally over millions of years. This contradicts the common assumption that plutons form from large, mobile bodies of magma. Incremental assembly is consistent with seismic results from active volcanic areas which rarely locate masses that contain more than $10 \%$ melt. At such a low melt fraction, a material is incapable of bulk flow as a liquid and perhaps should not even be termed magma. Volumes with higher melt fractions may be present in these areas if they are small, and this is consistent with geologic evidence for plutons growing in small increments. The large melt volumes required for eruption of large ignimbrites are rare and ephemeral, and links between these and emplacement of most plutons are open to doubt. We suggest that plutons may commonly form incrementally without ever existing as a large magma body. If so, then many widely accepted magma ascent and emplacement processes (e.g., diapirism and stoping) may be uncommon in nature, and many aspects of the petrochemical evolution of magmatic systems (e.g., in situ crystal fractionation and magma mixing) need to be reconsidered.
\end{abstract}

\section{INTRODUCTION}

Plutons are fundamental building blocks of the continental crust. Thought about plutons has been dominated by the tacit assumptions that plutons are largely molten during emplacement and that emplacement is geologically rapid (e.g., Buddington, 1959; Pitcher and Berger, 1972; Paterson et al.,
1996; Petford et al., 2000). If plutons are emplaced by bulk magmatic flow, then during emplacement, the magma must contain a melt fraction of at least 30-50 vol\% (Vigneresse et al., 1996). At lower melt fractions, crystals in the melt are welded to their neighbors; thus, a low melt-fraction material probably is better regarded not as magma but as a solid with melt-filled pore spaces because bulk flow of such a material requires pervasive solid-state deformation.

The concept of plutons as large ascending molten blobs (Fig. 1) is widespread in geologic thought and commonly guides interpretation of field relations (e.g., Buddington, 1959; Miller et al., 1988; Clarke, 1992; Bateman, 1992; Miller and Paterson, 1999). A contrasting view is that diapiric ascent of magma is too slow and energetically inefficient to be geologically important, and large magma bodies only form at the emplacement level where they are fed by dikes (e.g., Clemens and Mawer, 1992; Petford et al., 2000). Several lines of evidence indicate that, regardless of the ascent mechanism, at least some plutons were emplaced incrementally over time spans an order of magnitude longer than the thermal lifetime of a large magmatic mass (Coleman et al., 2004). No more than a small fraction of such a pluton can have contained melt at a given time, and thus apparently continuous bodies of plutonic rock appear to have grown in situ by amalgamation from many small, probably dike-fed, increments.

Magma volumes of $1000 \mathrm{~km}^{3}$ or more clearly must exist at least ephemerally in the crust because ignimbrite eruptions of this size are well known from the geologic record (Lipman, 1984). However, it need not follow that large plutons were

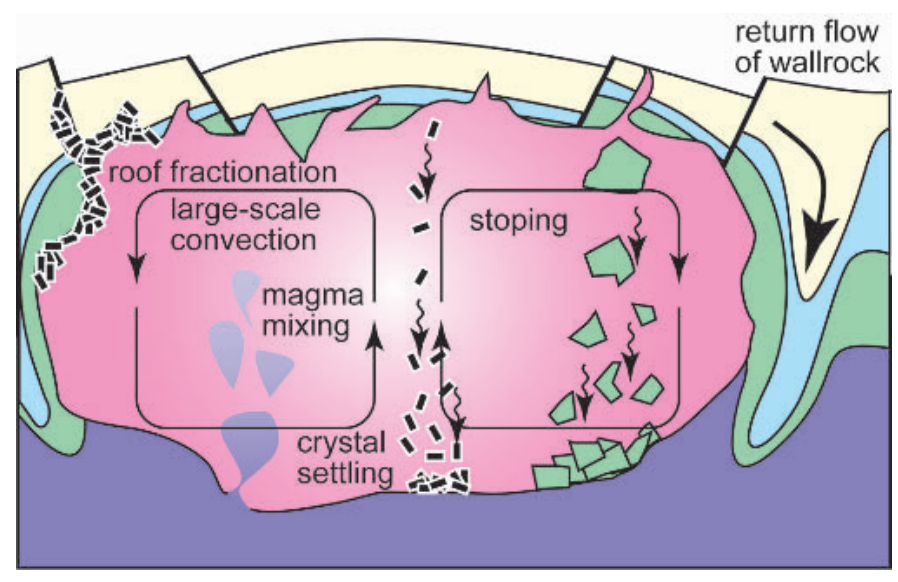

Figure 1. Sketch of the "big tank" magma chamber and a synopsis of the processes that are hypothesized to occur in and around rising magma bodies. Processes such as stoping, downward flow of wall rock, and ballooning (not explicitly represented) are invoked as material transfer and emplacement mechanisms. Processes such as sidewall crystallization, fractional crystallization, and magma mixing are invoked to account for geochemical variation of plutons and associated volcanic rocks. These processes all require large, highly molten magma chambers capable of flow as liquids.

*Present addresses: Gray-Department of Engineering Dynamics, Southwest Research Institute, P.O. Drawer 28510, San Antonio, TX 78249; TaylorU.S. Forest Service, Paonia Ranger District, P.O. Box 1030, Paonia, CO 81428 
once large tanks of unerupted magma. Large ignimbrite eruptions, although geographically widespread, happen rarely compared to the much smaller eruptions that construct volcanoes. If construction of plutons resembles that of volcanoes, plutons may represent amalgamations of many small magmatic additions. If so, then we must reevaluate pluton emplacement mechanisms and, indeed, reevaluate the concept of a "pluton."

This perspective mirrors the development of thought about mid-ocean ridge magmatism. A spreading center once was thought to contain a large permanent magma chamber that underwent in situ crystal fractionation and recharge (Cann, 1974). However, seismic studies failed to locate such magma chambers (e.g., Detrick et al., 1990), and modeling suggests that it is thermally difficult to maintain even a small permanent magma chamber at any but the most rapidly spreading mid-ocean ridge (e.g., Lister, 1983). Accretion of the oceanic crust now is envisioned in terms of small ephemeral magma bodies that differentiate by complex processes at many sites (Sinton and Detrick, 1992).

In this paper, we summarize field, geochronologic, and geophysical evidence that many plutons were emplaced incrementally over significant time spans and argue that many of our fundamental assumptions regarding plutons and their relationships to host rocks must be reexamined.

\section{EVIDENCE FOR INCREMENTAL EMPLACEMENT OF PLUTONS}

\section{Field Evidence}

A growing body of data suggests that many plutons were assembled as a series of sheet-like intrusions that may be gently or steeply inclined. Wiebe and Collins (1998) described the progressive growth of large plutons by vertical stacking of intrusive sheets beneath a longlived silicic magma cap and argued that a molten body of the size of the final pluton need never have existed. Similar large sheeted intrusions are now recognized worldwide and in many tectonic settings (e.g., Wiebe, 1993; Coleman et al., 1995; Brown and McClelland, 2000). Wiebe and Collins (1998) suggest that steeply dipping sheets at the margins of some plutons were emplaced subhori- zontally and then tilted at the margin of a sagging floor.

Other plutons preserve evidence for emplacement as a series of steep dikes (e.g., Pitcher, 1970; Hutton, 1992; McNulty et al., 1996). For example, the McDoogle pluton of the central Sierra Nevada displays compelling evidence for emplacement by dike amalgamation (Mahan et al., 2003). The pluton is compositionally layered parallel to its contacts and contains numerous thin concordant panels of wall rock that preserve consistent fabric orientations and tectonostratigraphic order. Wallrock bodies inside the pluton are interpreted to have remained in place as the pluton was intruded incrementally as a plexus of dikes (Mahan et al., 2003; cf. Pitcher, 1970).

The Tuolumne Intrusive Suite of Yosemite National Park has long been thought to have crystallized from several large batches of magma that were emplaced in rapid succession (Bateman and Chappell, 1979). However, at many places, the outer margin of the Tuolumne is clearly composed of granodiorite dikes that invaded wall rocks (Fig. 2). At May Lake the outermost unit of the Tuolumne in that area (tonalite of Glen Aulin) intrudes a screen of metamorphic wall rocks and is choked with wall-rock xenoliths (Fig. 3A), ranging from $250 \times 20 \mathrm{~m}$ down to decimeter scale, all of which contain foliation and lineation parallel to that in the main screen (Fig. 3B). The tonalite exhibits contact-parallel sheeting defined by variations in mineral proportions and grades over 5-25 $\mathrm{m}$ into the next inner and younger unit, the Half Dome Granodiorite. We interpret the xenoliths as in-place bodies of wall rock isolated by dikes that, where their contacts are not marked by xenoliths, are recorded by the compositional sheets.

The Half Dome Granodiorite near the contact also contains sheets of varying composition and tabular swarms of mafic enclaves, but grades inward to a more homogeneous rock. Here the occurrence of dikes or sheets is less certain. However, a pattern of dikes and sheets at the margins passing into a more homogenous interior is consistent with thermal models of incremental pluton growth that predict a transient sheeted-dike stage followed by forma- tion of a central, possibly small, steadystate magma chamber (Hanson and Glazner, 1995).

The growth of sheeted intrusions is analogous to that of crack-seal veins (Ramsay, 1980). A crack-seal vein contains a superficially uniform fill that accumulated incrementally as the crack opened in a series of discrete events. Annealing of the vein fill can obscure evidence of individual fracturing events, and this also may apply to composite plutons. McDoogle granodiorite has the same coarse grain size from the center of the pluton to the thinnest dike, and shows no outcrop-scale evidence of chilling at any contact. Locally, truncated mafic enclaves reveal steep internal dike contacts but, away from truncated enclaves, the dike contacts become invisible (Mahan et al., 2003). These observations suggest that rock textures were homogenized by post-emplacement annealing that obscured internal contacts. The textural homogeneity of large plutons like the Half Dome Granodiorite could also reflect post-emplacement annealing of amalgamated dikes or sheets, and such a pluton thus might contain any number of cryptic contacts. As yet it is unclear how to recognize and to map such cryptic contacts to determine their prevalence and abundance.

\section{Geochronologic Evidence}

Thermal models clearly show that crustal magma bodies should solidify rapidly, with small plutons cooling below the solidus in thousands of years and even large plutons in hundreds of thousands of years (e.g., Jaeger, 1957; Harrison and Clarke, 1979; Stimac et al., 2001). Figure 4 illustrates a simple two-dimensional thermal model of emplacement of a large rectangular magma body, comparable in width to the exposed Tuolumne Intrusive Suite. Temperatures were calculated using the HEAT program of Wohletz (2003). The magma body, silicic with an initial temperature of $900{ }^{\circ} \mathrm{C}$, is $5 \mathrm{~km}$ thick and $20 \mathrm{~km}$ wide, and its top is set at a depth of $15 \mathrm{~km}$ in a crust with a geothermal gradient of $20^{\circ} \mathrm{C} / \mathrm{km}$. The program calculates conductive cooling with a finite-difference solution to the heat flow equation, with latent heat of fusion released throughout the crystallization interval. 


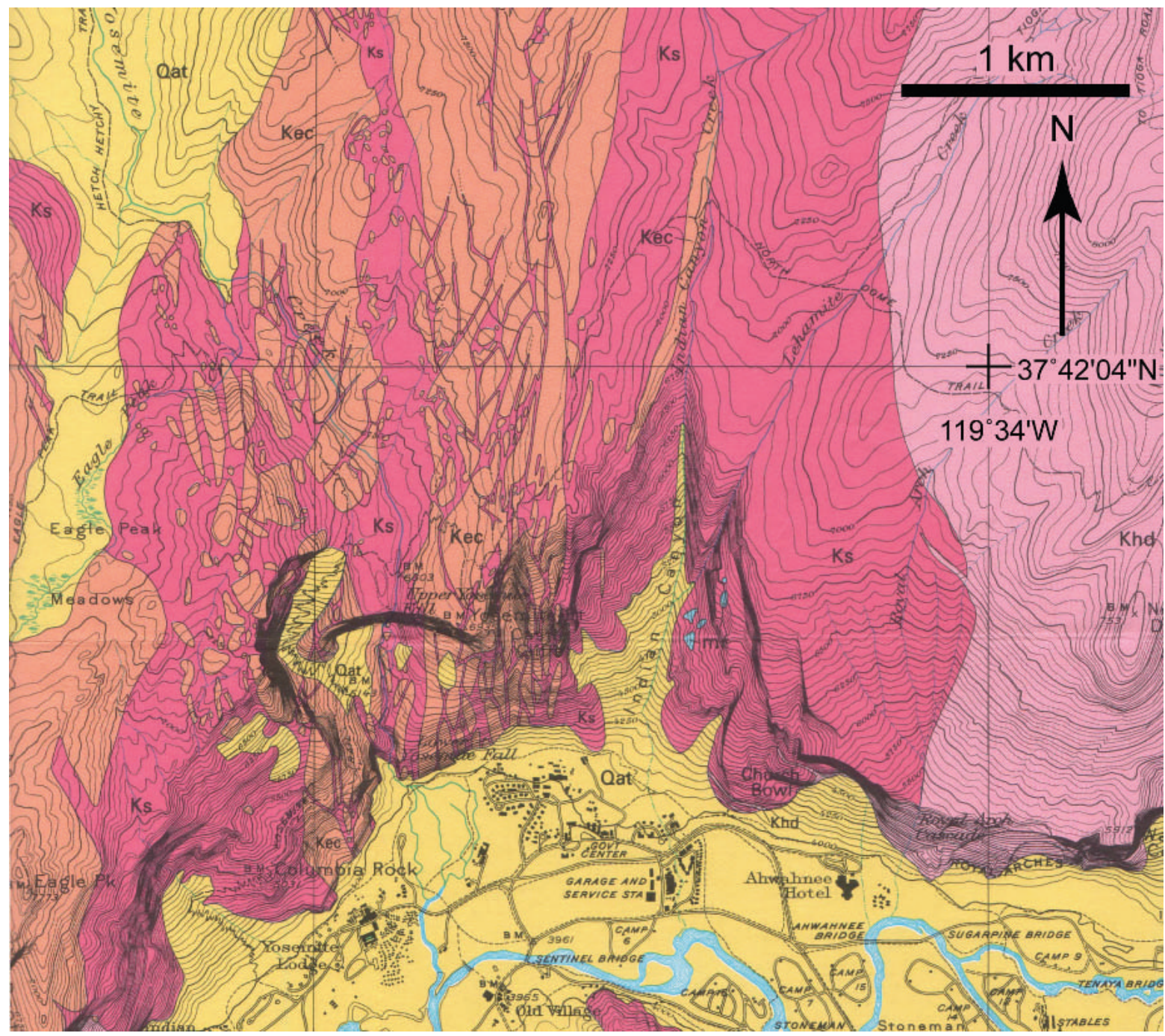

Figure 2. Geologic mapping around Yosemite Valley shows that outer, older units of the Tuolumne Intrusive Suite invaded older plutons as a series of dikes. Here, on the north side of Yosemite Valley near Yosemite Village, dikes of the outermost Tuolumne (here mapped as Sentinel Granodiorite, Ks) intruded and split off panels of the older El Capitan Granite (Kec). Map by Calkins (1985; mapped from 1913-1916); similar relations are shown farther north by Kistler (1973) and south of Yosemite Valley by Peck (2002). The mapped zone of dike emplacement stretches $\sim 15 \mathrm{~km}$ along strike (Huber et al., 1989) and continues beyond the mapped zone (see text).

Figure 4 tracks the temperature at four points within the body. All fall below $750{ }^{\circ} \mathrm{C}$ within 500,000 years, and the volume fraction of the pluton above $750{ }^{\circ} \mathrm{C}$ falls linearly to zero in that time. If $750^{\circ} \mathrm{C}$ is taken as an estimate of the temperature at which the magma is 50\% crystallized (and thus no longer mobile), then the mobile fraction is gone by 500,000 years. We note that this two-dimensional model cools significantly more slowly than a fully three-dimensional model because there is no heat loss out the ends, and that convection of fluids in the wall rocks will speed cooling greatly.

Geochronologic data contradict these results. In particular, $\mathrm{U}-\mathrm{Pb}$ zircon data from the Tuolumne Intrusive Suite (Coleman et al., 2004) demonstrate a regular time-space pattern of emplacement between 95 and $85 \mathrm{Ma}$, with the oldest intrusions at the margins and the youngest at the center (Fig. 5). The Half Dome Granodiorite was emplaced over a $>3$ m.y. period between $92.8 \pm 0.1$ and $88.8 \pm 0.8 \mathrm{Ma}$, with older ages near the outer contact and younger ages near the inner. The Half Dome Granodiorite is mapped as a single continuous pluton that locally grades into an inner porphyritic facies, but the data demonstrate a lifetime far longer than single-intrusion thermal models allow. Although the thermal modeling and geochronologic data permit the possibility that small volumes of partial melt may have persisted throughout the Half Dome during amalgamation, they do not permit the possibility that it intruded as a single batch of magma. The Half Dome thus must be cryptically composite and amalgamated from at least several discrete intrusions, the forms of which (e.g., dikes, subhorizontal sheets, blobs) are yet unknown. Pitcher (1993, p. 186) recognized multipulse plutonic systems that are emplaced over a significant time span, but stated that "the entire magmatic life of a multipulse pluton may not exceed a million years." Similarly, modeling by Petford et al. (2000) predicts intrusion over 1000 to $10,000,000$ years for a pluton the size of 



$\mathrm{Ka}$
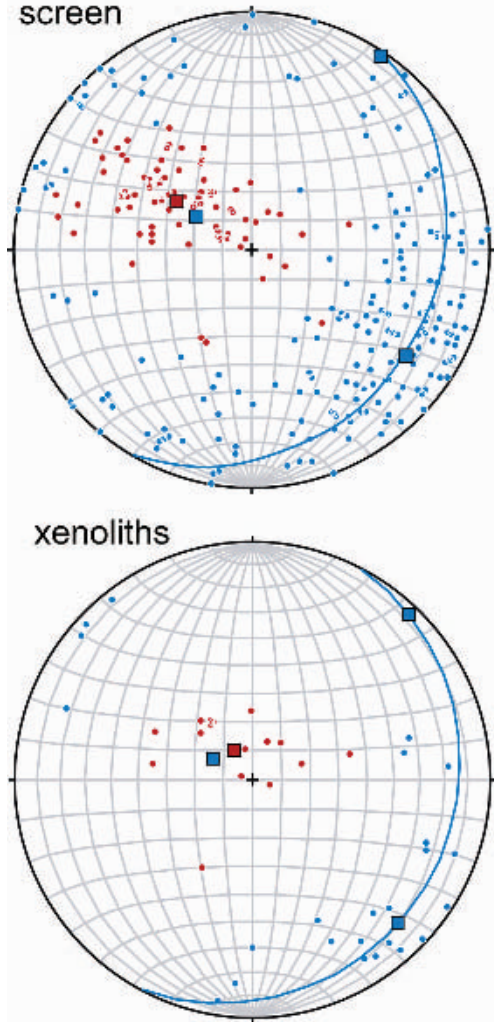

Figure 3. (A) Geologic map of the area around May Lake, Yosemite National Park, showing large xenoliths of metasedimentary rocks caught up in the outermost unit of the Tuolumne Intrusive Suite. From Taylor (2004). (B) Equal-area plots of structural data from May Lake. Lineation in red and poles to foliation in blue, with best-fit axes as squares. Data from the xenoliths, which are entirely enclosed in the tonalite of Glen Aulin, are consistent with data from the main metamorphic screen, indicating that the xenoliths were not reoriented during detachment, as would be expected of stoped blocks. These data are instead consistent with isolation of the xenoliths by diking. For foliation data, best-fit axes on girdle represent point maximum on girdle and the axis perpendicular to it.

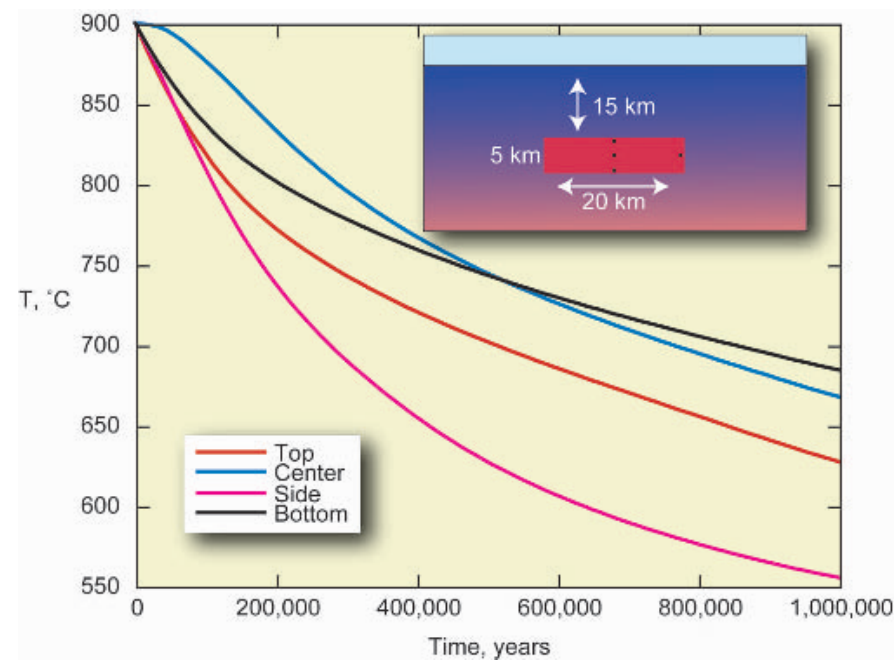

Figure 4. Evolution of temperatures in a two-dimensional magma body. Magma body, $5 \mathrm{~km}$ thick and $20 \mathrm{~km}$ wide, is emplaced at 15 $\mathrm{km}$ depth. Figure plots temperatures at four points in the body: $1 \mathrm{~km}$ below the top center, in the center, $1 \mathrm{~km}$ above the bottom center, and $1 \mathrm{~km}$ inside the side contact, vertically centered. The entire body is below $750{ }^{\circ} \mathrm{C}$ in ca. 500,000 years. The $>3$ m.y. lifetime of the Half Dome Granodiorite contradicts this single-pulse result. 


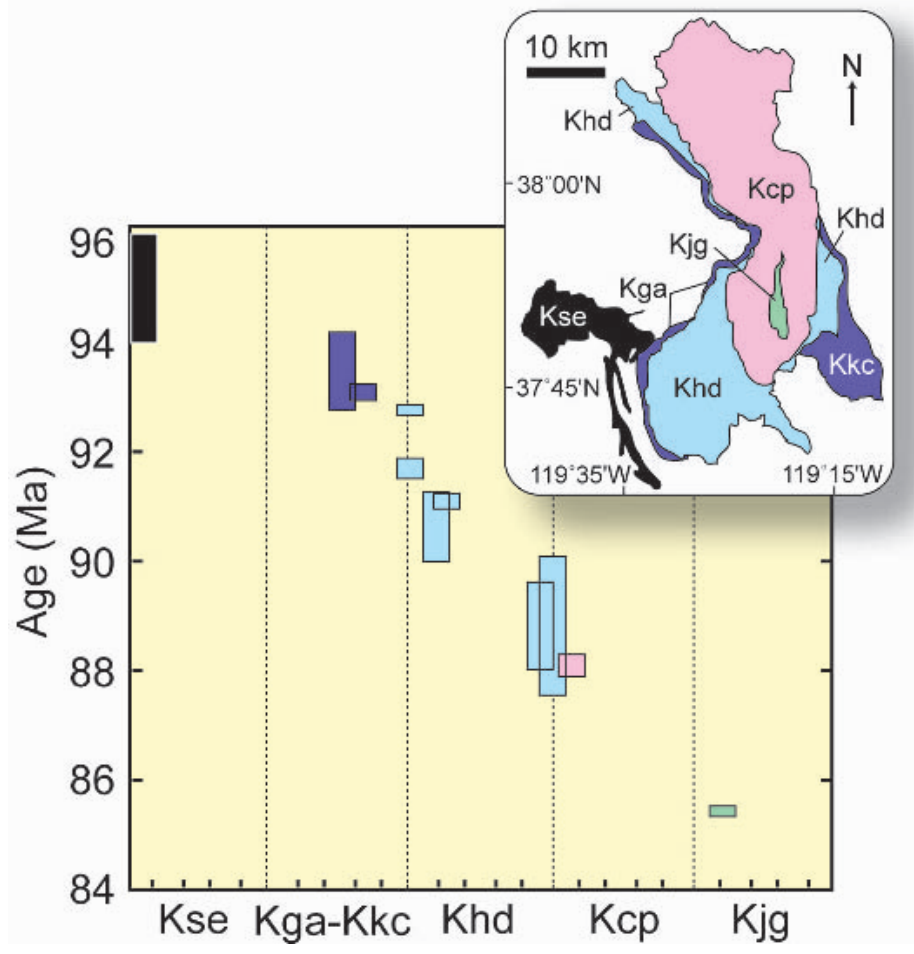

Figure 5. Summary of geochronologic data for the Tuolumne Intrusive Suite, modified from Coleman et al. (2004). Ages are from concordant $\mathrm{U}-\mathrm{Pb}$ zircon data. Bar height is equal to $\pm 2 \sigma$ error and bar color is keyed to rock unit color on inset map. Ages for units are arranged in sequence from outermost to innermost (KseSentinel Granodiorite; Kga-Kkc-tonalite of Glen Aulin-Kuna Crest Granodiorite; Khd—Half Dome Granodiorite; Kcp—Cathedral Peak Granodiorite; Kjg-Johnson Granite porphyry). Horizontal scale is not linear distance, but places samples according to the fractional distance from outer to inner contact of individual units (see Coleman et al. [2004] for a complete discussion).

the Tuolumne, but the authors prefer timescales of less than 100,000 years for large plutons. Our data indicate a magmatic lifetime closer to 10 m.y. for the Tuolumne Intrusive Suite.

Plutons like the Half Dome Granodiorite may be common. When large plutons are dated multiple times by the $\mathrm{U} / \mathrm{Pb}$ zircon method, it is fairly common for the resulting dates to disagree by more than analytical error (e.g., see Brown et al., 2000 , for several examples). The prevailing view that plutons cool in less than a million years requires such conflicting ages to reflect problems in isotopic systematics. However, it may be that many such age differences are real and that the problem lies instead with assumptions about plutonic processes.

\section{Seismic Evidence}

Active crustal magma bodies should be locatable using seismic methods because magmatic liquids slow and attenuate seismic waves. Hammond and Humphreys (2000) showed via finite-element calculations that just $2 \mathrm{vol} \%$ melt in the upper mantle should reduce $V_{\mathrm{p}}$ by $\sim 7 \%$ and $V_{\mathrm{s}}$ by $\sim 16 \%$. Because $S$-waves do not propagate through liquids, a body sufficiently molten to undergo bulk magmatic flow should not transmit Swaves and thus should produce a shadow zone.

Comprehensive surveys of major active volcanic areas have failed to turn up evidence for significant quantities of highly molten (>50\%) crustal magma (Iyer, 1984), and few clearly identifiable shadow zones are known in spite of careful surveys designed to find them (e.g., Sanders, 1993). Many areas are known worldwide in which partial melt is present, but decreases in P- and S-wave velocities are typically a few percent and rarely greater than 20\% (Lees, 1992; Nelson et al., 1996; Schilling and Partzsch, 2001; Zandt et al., 2003). Silicic volcanic centers in the western United States are inferred to have only a few percent of dispersed melt beneath them (Iyer et al., 1990). In the Cascade Range, "anomalous structures attributable to active magma chambers are generally small and difficult to detect" (Iyer et al., 1990).

Schilling and Partzsch (2001) used both electrical and seismic methods to estimate the amount of melt in the crust under the central Andes. They conclude that at least 20\% melt is required to explain observations, but that the absence of an S-wave shadow zone requires that such melt is localized in dikes and veins rather than forming large bodies of highly molten magma.

Therefore, wherever partially molten rocks have been seismically imaged, the melt fraction, at least over distances larger than the minimum resolution of the seismic data (typically $100-1000 \mathrm{~m}$ ), is small enough that bulk flow would require deformation of a solid crystalline framework. This appears to contradict the widespread assumption that active volcanic areas are underlain by large magma bodies in the process of cooling to form plutons. However, bodies with higher melt fractions may yet be present if they are too small to resolve seismically. This possibility is compatible with the geologic evidence summarized above for plutons that formed in small increments.

We conclude that, as at mid-ocean ridges, seismic evidence for large magma bodies with a high melt fraction is rare or absent. Massive caldera-forming eruptions may reflect either large magma bodies that are ephemeral and develop only rarely, or eruption of silicate melt that is relatively dispersed rather than concentrated in a single magmatic mass.

\section{WHY IS IT IMPORTANT TO RECOGNIZE INCREMENTALLY EMPLACED PLUTONS?}

If long-lived incrementally assembled plutons are common, then many widespread assumptions about the behavior of magma in the crust must be modified. These include the following.

\section{Pluton Ascent and Emplacement Mechanisms}

Diapirism, ballooning, and stoping are widely accepted processes that have been inferred for many plutons (e.g., Pitcher, 1993; Paterson et al., 1996). These processes require that plutons represent frozen magma chambers with at least $50 \mathrm{vol} \%$ liquid throughout a volume comparable to the size the pluton. This is not viable for any pluton that accumulated in small increments such that, at any time during its emplacement, most of the pluton was largely solid.

\section{Rates of Magmatic Processes}

Rates of pluton growth must be compatible with spacemaking rates in the wall rock (Paterson and Tobisch, 1992). A diapir must rise slowly and displace wall rocks by ductile 
creep (e.g., Miller et al., 1988). In contrast, the rate of magma ascent along dikes is rapid enough to allow construction of large plutons in as little as $10^{3}-10^{4}$ yr (Clemens and Mawer, 1992; Petford et al., 2000). Such volumetric emplacement rates imply extreme wallrock displacement rates of up to 0.1-1 $\mathrm{m} / \mathrm{yr}$, depending on the pluton shape and dilation pattern. However, a pluton may be incrementally assembled by dike injection at virtually any long-term rate, depending on the time between injection events. More detailed high-precision geochronologic studies of petrologically and tectonically diverse plutons are needed to discover the actual range of long-term pluton emplacement rates.

\section{Timing and Rates of Tectonic Processes}

If growth of an individual pluton can last millions of years, determining the ages of structures and fabrics by isotopic dating of cross-cutting plutons becomes less straightforward. A single pluton may both cut and be cut by structures if the pluton's magmatic lifetime overlaps deformation. These relationships could be exploited using careful isotopic dating to determine durations of events and to understand the interplay between intrusive and wall-rock processes.

\section{Interpretation of Magmatic Fabrics}

Interpretation of magmatic rock fabrics is controversial, and a review is beyond the scope of this paper. However, several plutons mentioned here (e.g., Half Dome, McDoogle) contain a magmatic fabric that appears continuous in the field in spite of field and geochronologic evidence that rocks containing the fabric crystallized at significantly different times. Such a fabric clearly is time-trangressive and implies notably uniform strain associated with emplacement increments added at significantly different times. In examples where a single magmatic fabric cuts contacts between mapped intrusive phases (e.g., Morgan et al., 2000), emplacing the plutons in small increments does not help resolve the problem but neither does it appear to increase the difficulties.

\section{Magmatic Differentiation Processes}

Large plutons commonly are compositionally zoned on length scales of
$10^{2}-10^{4} \mathrm{~m}$. Such zonation has been interpreted to result largely from crystal fractionation (e.g., Bateman and Chappell, 1979; Tindle and Pearce, 1981; Sisson and Moore, 1994) and/or magma mixing (Kistler et al., 1986; Frost and Mahood, 1987). However, for plutons assembled over millions of years with only small parts molten at one time, in situ crystal fractionation and/or magma mixing cannot account for the zonation. In such cases, textural and chemical homogeneity of a pluton probably reflects processes operating deeper than the observed crustal level. Indeed, a remarkable aspect of the Sierra Nevada is that the plutonic zoning of the Tuolumne-an outer, medium-grained, equigranular mafic granodiorite, a medial granodiorite with conspicuous euhedral hornblende, biotite, and titanite phenocrysts, and an inner granodiorite with large K-feldspar megacrysts-is repeated several times along the length of the range (Tikoff and Teyssier, 1992) among plutons of similar age. This repetition cannot reflect derivation of the plutons from a common magma chamber and must instead reflect the recurrence of petrogenetic processes in the deeper crust.

\section{Size and Nature of Magma Chambers}

There is a fundamental discrepancy between geophysical images of "large magma chambers" with volumes on the order of $10^{3} \mathrm{~km}^{3}$ but generally containing less than 10\% melt (Iyer et al., 1990) and the common petrologic view of a magma chamber with comparable dimensions but a melt fraction in excess of $50 \%$. Incremental emplacement of plutons by amalgamation of small intrusions is compatible with geophysical observations that indicate that magma chambers in the petrologic sense generally are small and transient.

\section{Correspondence between Plutons and Caldera-Forming Eruptions}

Caldera-forming eruptions with volumes on the order of $1000 \mathrm{~km}^{3}$ offer undeniable evidence that large magma bodies exist at least ephemerally in the crust. Growth of a magma body requires the rate of thermal input by magma to exceed the rate of thermal loss by cooling and eruption. In an area where the power input (Hildreth, 1981) is high, a large magma body can develop; where power input is low, cooling prevents development of a large magma body and a pluton may form incrementally (Fig. 6). It may be that, when power input is sufficiently high to form a large magma body in the upper to middle crust, the roof fails and a caldera-forming eruption results, evacuating the magma chamber to leave behind only minor plutonic residues. Neogene magmatism in the Basin and Range (Best et al., 1993), Sierra Madre Occidental of Mexico (McDowell and Clabaugh, 1979), and Bolivian Andes (de Silva, 1989) reflects large power input, development of dozens of large, shallow magma chambers, and common caldera collapse, but it is unknown if significant plutons were emplaced at the same time. However, caldera resurgence may be the surface manifestation of continued incremental input of magma to form newly amalgamating plutons.

\section{CONCLUSIONS}

Field and geochronologic evidence indicate that at least some large, superficially homogeneous plutons formed by amalgamation of numerous small intrusions, and that the field or petrologic record of their composite origins may be subtle. Coupled with the lack of geophysical evidence for modern large bodies of magma, this suggests that plutons may commonly form in many small increments in a manner analogous to growth of crack-seal veins. The resulting internal contacts apparently can be cryptic, and thus we know little as yet about typical geometric forms of individual increments or how the increments combine to form a pluton. However, present examples include plutons composed mainly of subhorizontal (e.g., Wiebe and Collins, 1998) and mainly of subvertical (e.g., Hutton, 1992; Mahan et al., 2003) intrusive sheets. A pluton composed of subhorizontal sheets will be laccolithic in overall form and likely have a gently dipping roof defined by the structurally highest intrusive sheet. A pluton composed of dikes should have an irregular roof at which the pluton grades into wall rock injected by many dikes, as is observed at one end of the McDoogle pluton.

The data cited above suggest that our understanding of the emplacement of 


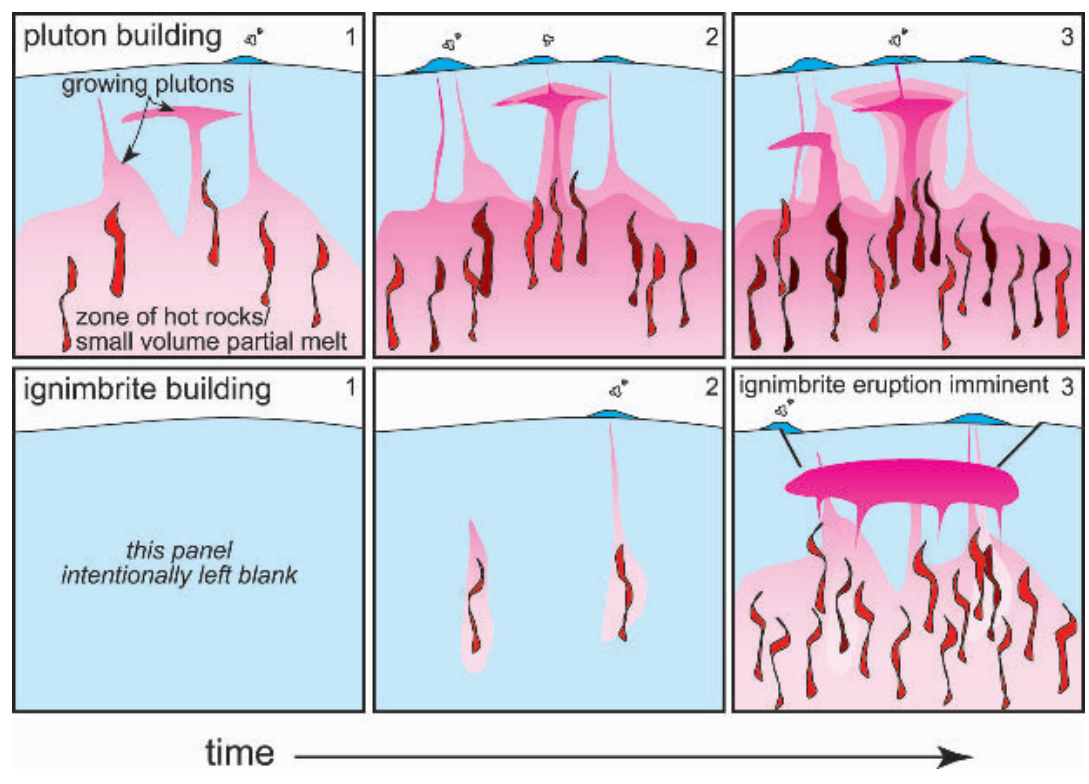

Figure 6. Sequence of sketches illustrating the differences between pluton building (top panels) and ignimbrite building (bottom panels). During pluton assembly, the flux of thermal energy (power; shown here schematically as new basalt intrusion—red dikes cooling to darker reds) is modest, yielding plutons assembled incrementally over millions of years and persistent volcanic activity. Only a small portion of the system need be liquid at any time (areas represented by darkest pinks). This model accounts for geochronologic, thermochronologic, and seismic observations discussed in text. Pluton growth is shown here via dike assembly at depth (perhaps preserved in plutons such as the McDoogle) feeding assembly of sheeted intrusions at shallower crustal levels (perhaps preserved in plutons such as the central Tuolumne). Initiation of an ignimbrite eruption is interpreted to result from rapid heat flux (high power) resulting in a large volume of highpercentage partial melt capable of eruption. We envision such magma chambers to be ephemeral features of the shallow lithosphere, erupting soon after formation. Note that for both sequences, the total energy input and silicic magma generated are intended to be approximately the same.

plutons and their chemical and structural evolution is incomplete, and the ideas presented here raise many questions and present testable hypotheses. Fruitful areas for future research might include:

- understanding the space-time pattern of incrementally emplaced plutons;

- reconsidering magmatic fabrics within the incremental growth framework;

- establishing clearer ties between the volcanic and plutonic records;

- understanding the chemical and petrologic evolution of plutons given that fractionation within, and mixing of, exposed units may be minimal;

- comparison of the emplacement rates of mafic versus felsic plutons; and

- comparison of incremental emplacement processes in varied tectonic settings.

\section{ACKNOWLEDGMENTS}

Research into plutonic processes in the Sierra Nevada was supported by National Science Foundation grants EAR-9526803 and EAR-9814789 to AFG, EAR-9814787 to JMB, and EAR-9814788 to DSC. We thank Kevin Mahan, Bob Wiebe, Bob Miller, Jonathan Miller, Ron Kistler, John Templeton, and many others for stimulating discussions about plutonic processes, although not all of them will agree with the ideas and conclusions that we present here. Thorough, critical, and creative reviews by Bernard Bonin, John Eichelberger, Rick Law, Calvin Miller, Robert Trumbull, and editor Keith Howard greatly improved both the science and presentation and gave us many new things to think about.

\section{REFERENCES CITED}

Bateman, P.C., 1992, Plutonism in the central part of the Sierra Nevada Batholith, California: U.S. Geological Survey Professional Paper, v. 1483, 186 p.

Bateman, P.C., and Chappell, B.W., 1979, Crystallization, fractionation, and solidification of the Tuolumne intrusive series, Yosemite National Park, California: Geological Society of America Bulletin, v. 90, p. 465-482.

Best, M.G., Scott, R.B., Rowley, P.D., Swadley, W.C., Anderson, R.E., Gromme, C.S., Harding, A.E., Deino, A.L., Christiansen, E.H., Tingey, D.G., and Sullivan, K.R., 1993, Oligocene-Miocene caldera complexes, ash-flow sheets, and tectonism in the central and southeastern Great Basin in Lahren, M.M., Trexler, J.H., Jr., and Spinosa, C., eds., Crustal evolution of the Great Basin and the Sierra Nevada: Reno, University of Nevada, p. 285-311.

Brown, E.H., and McClelland, W.C., 2000, Pluton emplacement by sheeting and vertical ballooning in part of the southeast Coast Plutonic Complex, British Columbia: Geological Society of America Bulletin, v. 112, p. 708-719.

Brown, E.H., Talbot, J.L., McClelland, W.C., Feltman, J.A, Lapen, T.J., Bennett, J.D., Hettinga, M.A., Troost, M.L. Alvarez, K.M., and Calvert, A.T., 2000, Interplay of plutonism and regional deformation in an obliquely convergent arc, southern Coast Belt, British Columbia: Tectonics, v. 19, p. 493-511.

Buddington, A.F., 1959, Granite emplacement with special reference to North America: Geological Society of America Bulletin, v. 70, p. 671-747.

Calkins, F.C., 1985, Bedrock geologic map of Yosemite
Valley, Yosemite National Park, California: U.S. Geological Survey Map I-1639, scale 1:24,000.

Cann, J.R., 1974, A model for oceanic crustal structure developed: Geophysical Journal of the Royal Astronomical Society, v. 39, p. 169-187.

Clarke, D.B., 1992, Granitoid rocks: London, Chapman and Hall, 283 p.

Clemens, J.D., and Mawer, C.K., 1992, Granitic magma transport by fracture propagation: Tectonophysics, v. 204, p. 339-360.

Coleman, D.S., Glazner, A.F., Miller, J.S., Bradford, K.J., Frost, T.P., Joye, J.L., and Bachl, C.A., 1995, Exposure of a Late Cretaceous layered mafic-felsic magma system in the central Sierra Nevada batholith, California: Contributions to Mineralogy and Petrology, v. 120, p. 129-136.

Coleman, D.S., Gray, W., and Glazner, A.F., 2004, Rethinking the emplacement and evolution of zoned plutons: Geochronologic evidence for incremental assembly of the Tuolumne Intrusive Suite, California: Geology, v. 32, p. 433-436.

de Silva, S.L., 1989, Altiplano-Puna volcanic complex of the Central Andes: Geology, v. 17, p. 1102-1106.

Detrick, R.S., Mutter, J.C., Buhl, P., and Kim, I.I., 1990, No evidence from multichannel reflection data for a crustal magma chamber in the MARK area on the Mid-Atlantic Ridge: Nature, v. 347, p. 61-64.

Frost, T.P., and Mahood, G.A., 1987, Field, chemical, and physical constraints on mafic-felsic magma interaction in the Lamarck Granodiorite, Sierra Nevada, California: Geological Society of America Bulletin, v. 99, p. 272-291.

Hammond, W.C., and Humphreys, E.D., 2000, Upper mantle seismic wave velocity; effects of realistic partial melt geometries: Journal of Geophysical Research, v. 105, p. 10975-10986.

Hanson, R.B., and Glazner, A.F., 1995, Thermal requirements for extensional emplacement of granitoids: Geology, v. 23 , p. $213-216$.

Harrison, T.M., and Clarke, G.K.C., 1979, A model of the thermal effects of igneous intrusion and uplift as applied to Quottoon Pluton, British Columbia: Canadian Journal of Earth Sciences, v. 16, p. 411-420.

Hildreth, W., 1981, Gradients in silicic magma chambers: implications for lithospheric magmatism: Journal of Geophysical Research, v. 86, p. 10153-10192. 
Huber, N.K., Bateman, P.C., and Wahrhaftig, C., 1989, Geologic map of Yosemite National Park and vicinity, California: U.S. Geological Survey Map I-1874, scale 1: 125,000 .

Hutton, D.H.W., 1992, Granite sheeted complexes: evidence for the diking ascent mechanism: Transactions of the Royal Society of Edinburgh: Earth Sciences, v. 83, p. 377-382.

Iyer, H.M., 1984, Geophysical evidence for the locations, shapes and sizes, and internal structures of magma chambers beneath regions of Quaternary volcanism: Philosophical Transactions of the Royal Society of London, Series A: Mathematical and Physical Sciences, v. 310, p. 473-510.

Iyer, H.M., Evans, J.R., Dawson, P.B., Stauber, D.A., Achauer, U., 1990, Differences in magma storage in different volcanic environments as revealed by seismic tomography; silicic volcanic centers and subduction-related volcanoes, in Ryan, M.P., Magma transport and storage: United Kingdom, John Wiley \& Sons, p. 293-316.

Jaeger, J.C., 1957, The temperature in the neighborhood of a cooling intrusive sheet: American Journal of Science, v. 255, p. 306-318.

Kistler, R.C., 1973, Geologic map of the Hetch Hetchy Reservoir Quadrangle, Yosemite National Park, California: U.S. Geological Survey Map GQ-1112, scale 1:62,500.

Kistler, R.W., Chappell, B.W., Peck, D.L., and Bateman, P.C., 1986, Isotopic variation in the Tuolumne Intrusive Suite, central Sierra Nevada, California: Contributions to Mineralogy and Petrology, v. 94, p. 205-220.

Lees, J.M., 1992, The magma system of Mount St. Helens: non-linear high-resolution P-wave tomography: Journal of Volcanology and Geothermal Research, v. 53, p. 103-116.

Lipman, P.W., 1984, The roots of ash flow calderas in western North America; windows into the tops of granitic batholiths: Journal of Geophysical Research, v. 89, p. 8801-8841.

Lister, C.R.B., 1983, On the intermittency and crystallization mechanisms of sub-seafloor magma chambers: Geophysical Journal of the Royal Astronomical Society, v. 73, p. $351-365$

Mahan, K.H, Bartley, J.M., Coleman, D.S., Glazner, A.F, and Carl, B.S., 2003, Sheeted intrusion of the synkinematic McDoogle pluton, Sierra Nevada, California: Geological Society of America Bulletin, v. 115, p. 1570-1582.

McDowell, F.W., and Clabaugh, S.E., 1979, Ignimbrites of the Sierra Madre Occidental and their relation to the tectonic history of western Mexico: Geological Society of America Special Paper 180, p. 113-124.

McNulty, B.A., Tong, W., and Tobisch, O., 1996, Assembly of a dike-fed magma chamber: The Jackass Lakes pluton, central Sierra Nevada, California: Geological Society of America Bulletin, v. 108, p. 926-940.

Miller, C.F., Watson, E.B., and Harrison, T.M., 1988, Perspectives on the source, segregation and transport of granitoid magmas: Transactions of the Royal Society of Edinburgh: Earth Sciences, v. 79, p. 135-156.

Miller, R.B., and Paterson, S.R., 1999, In defense of magmatic diapirs: Journal of Structural Geology, v. 21, p. 1161-1173.

Morgan, S.S., Law, R.D., and de Saint Blanquat, M., 2000, Papoose Flat, Eureka Valley-Joshua Flat-Beer Creek, and Sage Hen Flat plutons; examples of rising, sinking, and cookie-cutter plutons in the central White-Inyo Range, eastern California, in Lageson, D.R., Peters, S.G., and Lahren, M.M., eds., Great Basin and Sierra Nevada: Boulder, Colorado, Geological Society of America Field Guide 2, p. 189-204.

Nelson, K.D., Zhao, W., Brown, J., Che, J., Liu, X., Klemperer, S.L., Makovsky, Y., Meissner, R., Mechie, J., Kind, R., Wenzel, F., Ni, J., Nabelek, J., Chen L., Tan H., Wei, W. Jones, A.G., Booker, J., Unsworth, M., Kidd, W.S.F., Hauck, M., Alsdorf, D., Ross, A., Cogan, M., Wu, C., Sandvol, E.A. and Edwards, M., 1996, Partially molten middle crust beneath southern Tibet; synthesis of Project INDEPTH results: Science, v. 274, p. 1684-1688.

Paterson, S.R., and Tobisch, O.T., 1992, Rates of processes in magmatic arcs-implications for the timing and nature of pluton emplacement and wall rock deformation: Journal of Structural Geology, v. 14, p. 291-300.

Paterson, S.R., Fowler, T.K., Jr., and Miller, R.B., 1996, Pluton emplacement in arcs; a crustal-scale exchange process, in
Brown, M., et al., eds., The Third Hutton Symposium on the origin of granites and related rocks: Geological Society of America Special Paper 315, p. 115-123.

Peck, D.L., 2002, Geologic map of the Yosemite Quadrangle, central Sierra Nevada, California: U.S. Geological Survey Map I-2751, scale 1:62,500.

Petford, N., Cruden, A.R., McCaffrey, K.J.W., and Vigneresse J.-L., 2000, Granite magma formation, transport and emplacement in the Earth's crust: Nature, v. 408, p. 669-673.

Pitcher, W.S., 1970, Ghost stratigraphy in intrusive granites: a review, in Newall, G., and Rast, N., eds., Mechanism of Igneous Intrusion: Liverpool, Gallery Press, p. 123-140.

Pitcher, W.S., 1993, The nature and origin of granite: London, Blackie Academic \& Professional, 321 p.

Pitcher, W.S., and Berger, A.R., 1972, The geology of Donegal: a study of granite emplacement and unroofing, Regional geology series: New York, Wiley-Interscience, 435 p.

Ramsay, J.G., 1980, The crack-seal mechanism of rock deformation: Nature (London), v. 284, p. 135-139.

Sanders, C.O., 1993, Reanalysis of S-to-P amplitude ratios for gross attenuation structure, Long Valley caldera, California: Journal of Geophysical Research, v. 98, p. 22,069-22,079.

Schilling, F.R., and Partzsch, G.M., 2001, Quantifying partia melt fraction in the crust beneath the Central Andes and the Tibetan Plateau: Physics and Chemistry of the Earth, Part A: Solid Earth and Geodesy, v. 26, p. 239-246.

Sinton, J.M., and Detrick, R.S., 1992, Mid-ocean ridge magma chambers: Journal of Geophysical Research, v. 97 p. 197-216

Sisson, T.W., and Moore, J.G., 1994, Geologic map of the Giant Forest Quadrangle, Tulare County, California: U.S. Geological Survey, GQ-1751, 1:62,500.

Stimac, J.A., Goff, F., and Wohletz, K., 2001, Thermal modeling of the Clear Lake magmatic-hydrothermal system, California, USA: Geothermics, v. 30, p. 349-390.

Taylor, R.Z., 2004, Structure and stratigraphy of the May Lake interpluton screen, Yosemite National Park, Californi [M.S. thesis]: University of North Carolina at Chapel Hill, $60 \mathrm{p}$.

Tikoff, B., and Teyssier, C., 1992, Crustal-scale, en echelon "P-shear" tensional bridges-A possible solution to the batholithic room problem: Geology, v. 20, p. 927-930.

Tindle, A.G., and Pearce, A., 1981, Petrogenetic modelling of in situ fractional crystallization in the zoned Loch Doon Pluton, Scotland: Contributions to Mineralogy and Petrology, v. 78, p. 196-207.

Vigneresse, J.-L., Barbey, P., and Cuney, M., 1996 Rheological transitions during partial melting and crystallization with application to felsic magma segregation and transfer: Journal of Petrology, v. 37, p. 1579-1600.

Wiebe, R.A., 1993, The Pleasant Bay layered gabbro-diorite, coastal Maine; ponding and crystallization of basaltic injections into a silicic magma chamber: Journal of Petrology, v. 34 , p. $461-489$.

Wiebe, R.A., and Collins, W.J., 1998, Depositional features and stratigraphic sections in granitic plutons; implications for the emplacement and crystallization of granitic magma: Journal of Structural Geology, v. 20, p. 1273-1289.

Wohletz, K., 2003, KWare HEAT, version 4.06.0234 (06 June 2003) [cited 17 January 2004] [Internet], http: //www.ees1.lanl.gov/Wohletz/Heat.htm.

Zandt, G., Leidig M., Chmielowski, J., Baumont, D, and Yuan, X., 2003, Seismic detection and characterization of the Altiplano-Puna magma body, central Andes: Pure and Applied Geophysics, v. 160, p. 789-807.

\section{Manuscript submitted November 10,} 2003; accepted January 23, 2004. 